\title{
Explanatory social variables of under-5 mortality caused by injury in Isfahan Province, Islamic Republic of Iran
}

Zohre Hooshangi, ${ }^{1}$ Shayesteh Salehi² and Mostafa Amini-Rarani ${ }^{3}$

${ }^{1}$ Social Determinants of Health Research Center, Isfahan University of Medical Sciences, Isfahan, Islamic Republic of Iran; ${ }^{2}$ Community Health Research Center, Islamic Azad University, Isfahan (Khorasgan) branch, Isfahan, Islamic Republic of Iran. ${ }^{3}$ Health Management and Economics Research Center, Isfahan University of Medical Sciences, Isfahan, Islamic Republic of Iran (Correspondence to: Mostafa Amini-Rarani: m.amini@mng.mui.ac.ir).

\begin{abstract}
Background: Injuries are a major cause of disease, long-term disability and death. Injury-related damage accounts for $12 \%$ of the burden of disease worldwide. Recently, significant improvements in child health have been achieved in the Islamic Republic of Iran: under-5 mortality was reduced substantially from 1990 to 2013. Nevertheless, injury is still a significant cause of mortality in this age group.

Aims: Because of their vulnerability and the high rates of injury-related mortality among children under-5, this study aimed at investigating explanatory social variables of injury-related mortality.

Methods: The study was conducted using the Commission on Social Determinants of Health conceptual framework among children aged under-5 years in Isfahan Province. Using the national child mortality surveillance system 1433 under-5 mortalities during 2010-2015 were secondary analysed.

Results: We found 403 (28\%) cases were related to injury. Most of the deaths occurred in 706 infants (49.2\%), among boys (54.8\%) and urban residents (78.9\%). Multivariate logistic regression showed that mothers' low education level, age 1-5 years', living in a supportive centre and having financial problems increased the odds of under-5 mortality caused by injury (odds ratio > 1, $P$-value $\leq 0.05$ ).

Conclusion: Considering the importance and impacts of social factors on injury-related mortality among children, health policy-makers should initially consider the social determinants of health approach in child health programmes to inform interventions aimed at reducing injury-related mortality.

Keywords: child mortality, injury, social determinants of health, Iran

Citation: Hooshangi Z; Salehi S; Amini-Rarani M. Explanatory social variables of under-5 mortality caused by injury in Isfahan Province, Islamic Republic of Iran. East Mediterr Health J. 2020;26(6):660-667. https://doi.org/10.26719/emhj.19.086

Received: 15/10/17; accepted: 16/08/18

Copyright (c) World Health Organization (WHO) 2020. Open Access. Some rights reserved. This work is available under the CC BY-NC-SA 3.0 IGO license (https://creativecommons.org/licenses/by-nc-sa/3.o/igo)
\end{abstract}

\section{Introduction}

Today, injuries are one of the major concerns in public health in the category of noncommunicable disease (1); they are a major cause of disease, long-term disability and death in most countries (2). Injury-related conditions account for $12 \%$ of the burden of disease and for the high level of unintentional mortality at the global level (3). According to a 2014World Health Organization report, injuries give rise to more than 5 million deaths annually, i.e. $9 \%$ of the world's deaths (4). Further, non-fatal consequences of injuries include hospitalization, temporary or permanent disability, and mental disorders (4).

Although injuries are viewed as a predictable phenomenon (5), they remain a growing problem in developing countries, and are forecast to be the second greatest cause of disability in these countries till 2020. Because of their physiological and developmental limitations and behavioural characteristics, children are one of the most vulnerable groups; injuries are common and have critical importance, especially in developing countries (6). Given their vulnerability to injuries (7) and the high rates of child injury mortality, childhood injuries are a major priority, as well as a public health issue (8). Childhood injuries not only lead to high rates of mortality but also cause high rates of disability: thousands of children are condemned to spending the rest of their lives with disability (4). In addition to those who die from injuries each year, children who survive may require continuous rehabilitation care that affects all aspects of their life and their family's livelihood.

A 2010 study on assessing the cause of mortality in the Islamic Republic of Iran showed that unintentional injuryrelated mortalities and traffic-related mortalities accounted for 6.7 and $4.2 \%$ of under- 5 mortalities respectively (9). Also, the most common causes of children mortality are: traffic accidents $(43.0 \%)$, closure of the respiratory tract (10.7\%), drowning (9.7\%), burns (7.3\%), and falls (6.8\%) (10).

Globally, under-5 mortality was reduced from 90.6 to 42.5 per 1000 live births, and annual under-5 mortality rates were reduced from 12.7 million to 5.9 million in 2015 (11). In the Islamic Republic of Iran, trends show that during recent years, significant improvements have been achieved in child health. According to a 2014 report, under-5 mortality was reduced from 107000 in 1990 to 25 000 in 2013 (12). Despite this substantial reduction, injury is still one of the significant causes of mortality in this age group. 
Currently, health approaches are much wider and biomedical approaches to health and disease have shifted to social context approaches; special attention is also being paid to nonmedical determinants of health. Each of these, including the social determinants, has a significant effect on health, either directly or indirectly, so they are called "the causes of the causes" (13). That is, social determinants of health, such as income, education, occupation, nutrition, social class, the health system and so on, have an important impact on health or ill health. If these are overlooked, it is difficult to achieve the desired health goals and improve health system performance (14). Considering the importance and prevalence of injury-related mortality among children and the increasing trend worldwide (15), and given the role of social-related factors in the recognition, prevention and reduction of such mortality, the current study aimed at investigating the explanatory social variables of under-5 mortality caused by injury in Isfahan Province during 2010-2015.

\section{Methods}

\section{Data}

This study was a cross-sectional secondary analysis of data, which extracted the required data from the national child mortality surveillance system. All under-5 mortalities (1433) in Isfahan Province during 2010-2015 were analysed.

\section{Setting and population}

Isfahan is one of the largest and most important cities in central Asia and is located in the centre of the Islamic Republic of Iran. According to the 2011 Iranian population and housing census, the population of the Isfahan Province is 4879312 (50.74\% male, $49.26 \%$ female); approximately 4.16 million $(85.4 \%)$ reside in urban areas, 0.71 million (14.6\%) in rural areas and the rest are residents of nomadic areas (16). The majority of men $(90.70$ $\%)$ and women $(84.75 \%)$ in the province are literate: around $3.6 \%$ of the population are foreigners, mostly from Afghanistan and Iraq.

\section{Definition of variables}

Social variables for the current study were selected based on the Commission on Social Determinants of Health conceptual framework (17). This categorizes the factors that affect the distribution health and well-being in the society in three levels: socioeconomic and political context; structural determinants and socioeconomic status; and intermediary determinants. With regard to the availability of information, we analyzed the relationship between traffic and non-traffic injury-related mortality with certain structural factors, including mother's education, household's financial problems and nationality and certain intermediary factors including biological (age, sex and history of chronic diseases), living conditions, environmental (area of residence) and health system-related factors (physical access to medicine, laboratory, radiology and ambulance services. Non-traffic injuries include: closure of respiratory tract, poisoning, falling, contact with electricity, drowning, burns, being hit with a hard object, and so on. The age variable was categorized into 3 groups: neonate ( $<28$ days), infant ( $<1$ year), and $1-5$ years old. Data on household financial problems were collected through a question in the national child mortality surveillance system: households were asked whether or not they have had financial problems.

\section{Statistical analysis}

Data were extracted, prepared and entered into STATA/ SE, version 14. Then, data were analysed on 2 levels: descriptive (frequency and percent) and inferential (univariate and multivariate logistic regression). Since the outcome variable (under- 5 mortality caused by injury) is binary (whether or not mortality is caused by injury), logistic regression was employed to calculate the odds ratio (OR) for the explanatory variables. To this end, first, univariate logistic regression between under-5 mortality caused by injury and each explanatory variable was calculated. Variables with a statistical significance level $\leq 0.05$ were included in the multivariate logistic regression. To measure the fitness of the model and its forecasting power, the Pearson $\chi^{2}$ test and the pseudo $\mathrm{R}^{2}$ were used.

\section{Ethical approval}

This study received the required ethics approval from Islamic Azad University of Isfahan (Khorasgan branch) Research Ethics Committee with ethical code No: IR.IAU. NAJAFABAD.REC.1395.9.

\section{Results}

Of the 1433 child mortalities in Isfahan in 2010-2015, $403(28.1 \%)$ were injury-related (traffic and non-traffic) and $1030(71.8 \%)$ were related to other factors. Most of the mothers, 599 (42.2\%), had an education level under high school diploma; only 127 (9.4\%) attended university (Table 1). The majority of deaths were among boys and infants. The majority of children were living in urban areas. Most of the children were living in 2-parent families, had physical access to medicine and diagnostics centres, were transferred by ambulance and did not have any chronic diseases.

During 2010-2015, the proportion of some causes of injury-related mortality was reduced and for some others it increased (Figure 1). Closure of the respiratory tract showed the highest reduction, $25.1 \%$. However, despite an $8.5 \%$ reduction in traffic injuries, such incidents were still among the major causes of mortality. Among the others, drowning accounted for a $7.8 \%$ increase and falls for $2.6 \%$.

The univariate logistic regression showed that the relationship between under-5 mortality caused by injury and all the structural and intermediary variables (except for nationality) was statistically significant (P-value < 0.05). Accordingly, nationality was excluded 
Table 1 Descriptive characteristics of children from the under-5 mortality records in Isfahan $(n=1433)(2010-2015)$

\begin{tabular}{|c|c|c|}
\hline Characteristic & No. & $\%$ \\
\hline \multicolumn{3}{|c|}{ Structural } \\
\hline \multicolumn{3}{|l|}{ Maternal education } \\
\hline Illiterate & 185 & 13.7 \\
\hline Below high school diploma & 599 & 44.2 \\
\hline High school Diploma & 440 & 32.5 \\
\hline University degree & 127 & 9.4 \\
\hline \multicolumn{3}{|l|}{ Household's financial problems } \\
\hline Yes & 384 & 40.2 \\
\hline No & 571 & 59.7 \\
\hline \multicolumn{3}{|l|}{ Nationality } \\
\hline Iranian & 1340 & 93.5 \\
\hline Foreign & 93 & 6.4 \\
\hline \multicolumn{3}{|c|}{ Intermediary } \\
\hline \multicolumn{3}{|l|}{ Age } \\
\hline Neonate (<28 days) & 170 & 11.8 \\
\hline Infant $(<1$ year $)$ & 706 & 49.2 \\
\hline $1-5$ years & 557 & 38.8 \\
\hline \multicolumn{3}{|l|}{ Sex } \\
\hline Male & 786 & 54.8 \\
\hline Female & 647 & 45.1 \\
\hline \multicolumn{3}{|l|}{ History of chronic diseases } \\
\hline Yes & 453 & 38.4 \\
\hline No & 726 & 61.5 \\
\hline \multicolumn{3}{|l|}{ Residence } \\
\hline Urban & 1131 & 78.9 \\
\hline Rural & 295 & 20.6 \\
\hline Nomadic & 7 & 0.5 \\
\hline \multicolumn{3}{|l|}{ Child's living status } \\
\hline Living with 2 parents & 1250 & 87.2 \\
\hline Living with mother & 91 & 6.3 \\
\hline Living with father & 33 & 2.3 \\
\hline Living with relatives & 18 & 1.2 \\
\hline Living in supportive centres & 19 & 1.3 \\
\hline Other & 22 & 1.5 \\
\hline \multicolumn{3}{|l|}{ Physical access to medicine } \\
\hline Yes & 713 & 65.3 \\
\hline No & 379 & 34.7 \\
\hline \multicolumn{3}{|c|}{ Physical access to laboratory or radiology } \\
\hline Yes & 698 & 65.9 \\
\hline No & 361 & 34.1 \\
\hline \multicolumn{3}{|l|}{ Physical access to ambulance } \\
\hline Yes & 720 & 65.0 \\
\hline No & 385 & 35.0 \\
\hline
\end{tabular}

in the multivariate logistic regression model. Table 2 shows the multivariate logistic regression as the final model between under- 5 mortality caused by injury and the selected explanatory variables. The OR for injury- related mortality in children of mothers with education less than diploma level was 2.01 compared with children of mothers with a university degree, i.e. education below diploma level among mothers doubled the odds of injury-related mortality in children. Having financial problems increased the odds of under- 5 mortality caused by injury to 1.42 .

For children aged 1-59 months, the OR was 1.87 compared with neonates (Table 2). The odds of mortality caused by injury was 1.38 times higher in boys than in girls. Chronic disease was a protective factor against injury-related mortality, i.e. children with a chronic disease were less likely (OR 0.7) to die from injury than children with no history of chronic disease. The OR for injury-related mortality was 0.06 for urban and 0.14 for rural areas, i.e. children living in nomadic areas had a much greater risk of mortality. Living with a single parent or with other relatives or growing up in care centres increased the odds of injury-related mortality (OR $1.17,1.36$ and 1.58 , respectively), compared with situations where children live in a 2-parent family. Children who were not living with their either or both parents had a higher risk of injury-related mortality (Table 2). Physical access to medicine, laboratory/radiology and ambulance services reduced injury-related under-5 mortality (OR $0.14,0.26$ and 0.28 respectively).

To estimate goodness of fit, the Pearson $\chi^{2}$ test was used. Our results showed that the explanatory variables we employed were highly illustrative of injury-related mortality. In the logistic regression, pseudo $\mathrm{R}^{2}$ showed that the explanatory variables explained $33 \%$ of variance variation for injury-related mortality.

\section{Discussion}

Generally, our study showed that certain structural and intermediary factors were risk factors for under- 5 mortality caused by injury. Other factors, including residence in an urban area, physical access to health care services and history of chronic disease, were protective.

The findings of the current study are, to some extent, both consistent and inconsistent with those of other studies. The odds of injury-related mortality in boys was $36 \%$ higher than in girls. Studies conducted in the Islamic Republic of Iran $(18,19)$ and Egypt $(20)$ have also shown that the proportion of deaths is higher in boys. In our study, children aged 1-5 years have higher odds ratio for death than neonates; conversely, in an Iranian study, children aged 1-11 months had the highest odds ratio for death (19). Our findings showed that the odds of injury-related mortality was higher in children living in a nomadic population than those living in urban and rural areas. It appears that factors such as lack of medical equipment and treatment facilities, insecure environment, inappropriate roads, high mobility and parents' unawareness have a role in the greater risk of injury-related mortality in nomadic populations. Delbarpoor et al. found that children living in rural areas had a higher risk of injury-related mortality (19). In Bangladesh, Chowdhury and Huda also showed 


\begin{tabular}{|c|c|c|c|c|c|}
\hline Characteristic & Coefficient & SE & OR & P-value & $95 \% \mathrm{CI}$ \\
\hline & \multicolumn{5}{|c|}{ Structural } \\
\hline \multicolumn{6}{|l|}{ Maternal education } \\
\hline Illiterate & 0.243 & 0.563 & 1.27 & 0.186 & $0.412-3.450$ \\
\hline Below high school diploma & 0.702 & 0.458 & 2.01 & 0.012 & $1.831-4.563$ \\
\hline High school diploma & 0.522 & 0.456 & 1.68 & 0.252 & $0.685-4.125$ \\
\hline University degree ${ }^{a}$ & - & - & 1 & - & - \\
\hline \multicolumn{6}{|l|}{ Household's financial problems } \\
\hline Yes & 0.427 & 0.269 & 1.42 & 0.012 & $1.093-2.141$ \\
\hline \multirow[t]{2}{*}{$\mathrm{No}^{\mathrm{a}}$} & - & - & 1 & - & - \\
\hline & \multicolumn{5}{|c|}{ Intermediary } \\
\hline \multicolumn{6}{|l|}{ Age } \\
\hline Neonate $^{\mathrm{a}}(<28$ days $)$ & - & - & 1 & - & - \\
\hline Infant ( $<1$ year) & 0.454 & 0.525 & 1.35 & 0.512 & $0.554-4.350$ \\
\hline $1-5$ years & 0.735 & 0.510 & 1.87 & $<0.001$ & $1.45-5.416$ \\
\hline \multicolumn{6}{|l|}{ Sex } \\
\hline Male & 0.322 & 0.254 & 1.38 & 0.024 & $1.152-2.254$ \\
\hline Female $^{a}$ & - & - & 1 & - & - \\
\hline \multicolumn{6}{|l|}{ History of chronic disease } \\
\hline Yes & -0.652 & 0.384 & 0.07 & $<0.001$ & $0.032-0.146$ \\
\hline $\mathrm{No}^{\mathrm{a}}$ & - & - & 1 & - & - \\
\hline \multicolumn{6}{|l|}{ Residence } \\
\hline Urban & -0.726 & 0.426 & 0.06 & 0.010 & $0.011-0.510$ \\
\hline Rural & -0.537 & 0.284 & 0.14 & 0.018 & $0.019-0.646$ \\
\hline Nomadic $^{\mathrm{a}}$ & - & - & 1 & - & - \\
\hline \multicolumn{6}{|l|}{ Child's living status } \\
\hline Living with 2 parents ${ }^{a}$ & - & - & 1 & - & - \\
\hline Living with mother & 0.151 & 0.116 & 1.17 & $<0.001$ & $0.392-3.263$ \\
\hline Living with father and other relatives & 0.478 & 0.347 & 1.36 & $<0.001$ & $0.094-4.575$ \\
\hline Living in supportive centres and other places & 0.562 & 0.422 & 1.58 & $<0.001$ & $0.424-2.613$ \\
\hline \multicolumn{6}{|l|}{ Physical access to medicine } \\
\hline Yes & $0.445^{-}$ & 0.380 & 0.14 & $<0.001$ & $0.045-0.460$ \\
\hline $\mathrm{No}^{\mathrm{a}}$ & - & - & 1 & - & - \\
\hline \multicolumn{6}{|l|}{ Physical access to laboratory or radiology } \\
\hline Yes & $0.036-$ & 0.025 & 0.26 & 0.026 & $0.022-0.779$ \\
\hline $\mathrm{No}^{\mathrm{a}}$ & - & - & 1 & - & 1 \\
\hline \multicolumn{6}{|l|}{ Physical access to ambulance } \\
\hline Yes & $0.317-$ & 0.249 & 0.28 & $<0.001$ & $0.173-0.464$ \\
\hline $\mathrm{No}^{\mathrm{a}}$ & - & & 1 & - & - \\
\hline Coefficient of determination & \multicolumn{5}{|c|}{ Pseudo $R^{2}=0.330$} \\
\hline Likelihood ratio & \multicolumn{5}{|c|}{$\chi^{2}=223.00 ; P<0.001$} \\
\hline Pearson's goodness of fit test & \multicolumn{5}{|c|}{ Pearson $\chi^{2}=582.91 ; P<0.001$} \\
\hline
\end{tabular}

$S E=$ standard error; $O R=$ odds ratio; $C I=$ confidence interval.

${ }^{a}$ Reference category.

${ }^{d}$ Kruskal-Wallis test was used to compare differences for continuous variables and the Pearson chi-squared was used for categorical variables.

that under-5 mortality was higher in rural than in urban areas $(21,22)$, which is consistent with our findings. It is worth noting that children living in urban areas are more exposed to traffic-related injury than those living in rural areas or in a nomadic population, but at the same time they have better access to health care services. Therefore, despite the higher prevalence of traffic injuries among children living in urban areas, because of more access to 


\section{Figure 1 Distribution of cause of death according to type of injury in children under-5 years in Isfahan (2010-2015)}

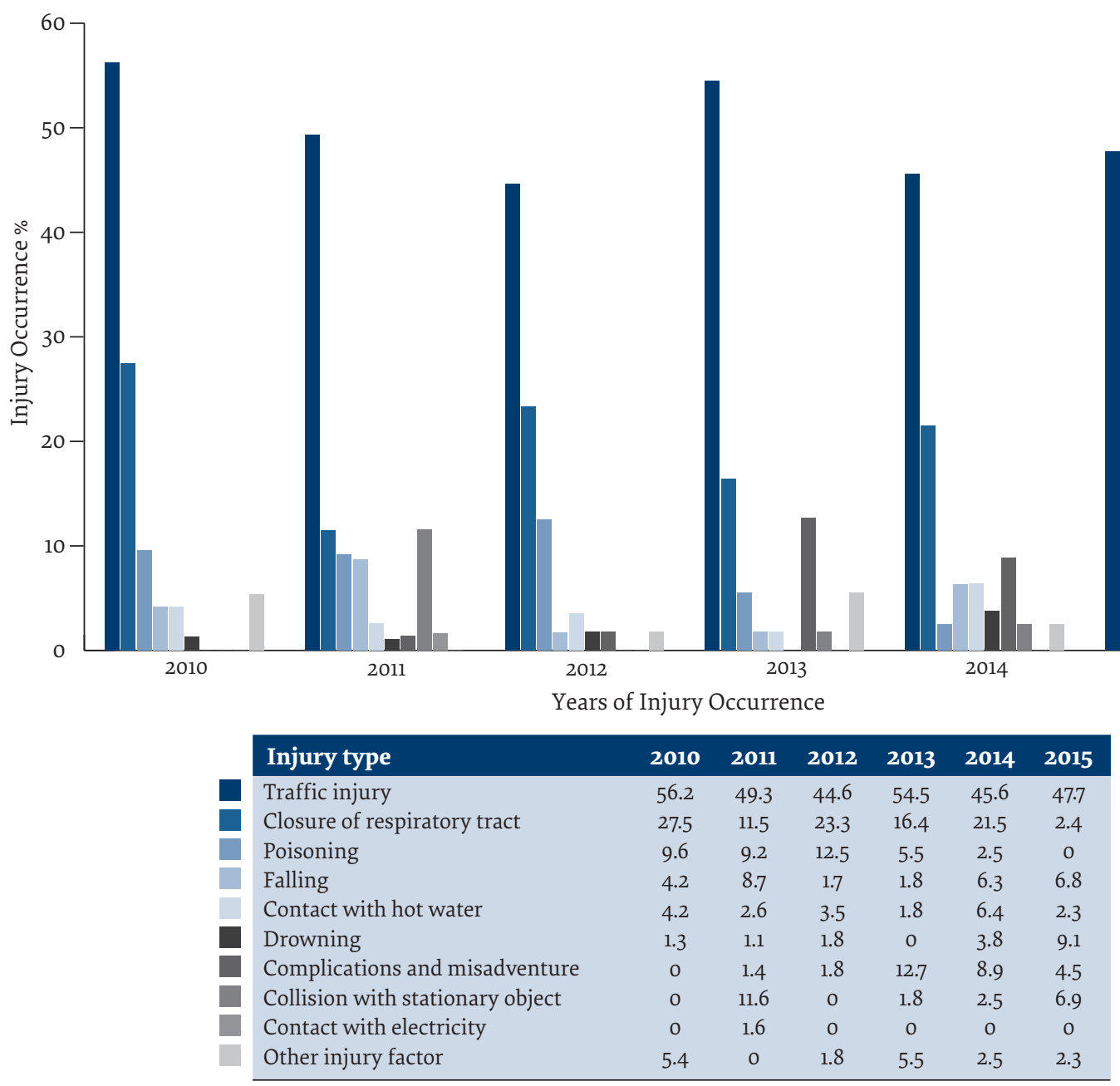

health care services, their chance of survival is higher.

Our results showed that children not living with both parents, had higher odds of injury-related mortality. It can be concluded that living with a single parent because of work pressures $(23,24)$ or depression $(25)$ reduces the protective power of the parent and therefore increases injury-related mortality.

Mother's education is one of the social determinants of injury-related mortality. As we observed, children whose mother's education was under diploma level had higher odds of injury-related mortality. Studies conducted in the Islamic Republic of Iran $(18,19,26)$, India (27) and Sudan (28) showed that a higher level of education among mothers associated with a lower rate of injury-related mortality. It should be noted that mother's education, directly and indirectly, improves health, i.e. an educated mother, in comparison with an uneducated mother, is more aware of benefits of healthy behaviour and has greater knowledge, both of which affect a child's access to preventive and health care services (15).

The household's access to health care services (physical access to medicine, laboratory, radiology and ambulance) is among those social factors of health which directly affect injury-related mortality. In Nepal, Kravdal showed that using health care services can reduce injuryrelated mortality among children (29). To explain this issue it can be said that as access to health care services and facilities improves, the opportunity to use them increases, which consequently prevents undesired health outcomes, including injury-related mortality.

This study showed that financial problems increase the odds of injury-related mortality. The findings of other studies conducted in the Islamic Republic of Iran (30-32), Bangladesh (22) Sudan (28) and the Czech Republic (33) are also consistent with our findings. Children living in wealthy families are likely to be healthier (physical, mental and social health) than those who are not. Income poverty, through poor access to health care services, food insecurity, inappropriate housing conditions, residence in disadvantaged areas, etc., negatively affect the health situation and result in high mortality.

In regard to the protective effect of having chronic disease on injury-related mortality, it is likely that, because of their physical, mental or developmental problems, children with chronic disease are more carefully protected by their parents and engage in physical activities less often. Thus, such children are less likely to be at risk of injury. 


\section{Conclusion}

As to the importance and effects of social factors on injury-related mortality in children, the social determinants of health approach needs to be taken into account in health policy-making for children. Specifically, more attention should be paid to education, household income, sex and children's living status to reduce child injury-related mortality. This may be achieved through intersectoral collaboration.

Funding: The present study was funded by the Islamic Azad University, Isfahan (Khorasgan) Branch, as an MSc thesis, research code 23810403951008 .

Competing interests: None declared.

\section{Variables sociales explicatives de la mortalité des moins de 5 ans due à des traumatismes dans la province d'Ispahan (République islamique d'Iran)}

\section{Résumé}

Contexte : Les traumatismes constituent une cause majeure de morbidité, d'incapacité à long terme et de mortalité. Les dommages liés aux traumatismes représentent $12 \%$ de la charge de morbidité dans le monde. Récemment, des améliorations significatives en matière de la santé infanto-juvénile ont été réalisées en République islamique d'Iran : la mortalité des moins de 5 ans a considérablement diminué entre 1990 et 2013. Néanmoins, les traumatismes continuent d'être une cause majeure de mortalité pour ce groupe d'âge.

Objectifs : Du fait de la vulnérabilité des enfants de moins de 5 ans et des taux élevés de mortalité liée à des traumatismes dans ce groupe d'âge, la présente étude visait à examiner certaines variables sociales explicatives de la mortalité due à des traumatismes.

Méthodes : La présente étude a été menée selon le cadre conceptuel «Commission des déterminants sociaux de la santé » auprès d'enfants de moins de 5 ans dans la province d'Ispahan. Selon le système national de surveillance de la mortalité infanto-juvénile, 1433 décès d'enfants de moins de 5 ans survenus entre 2010 et 2015 ont fait l'objet d'une analyse secondaire.

Résultats : Les résultats ont montré que 403 cas (28\%) étaient liés à un traumatisme. La plupart des décès concernaient des nourrissons (706, soit 49,2\%), des enfants de sexe masculin (54,8 \%) et des citadins (78,9\%). L'analyse de régression logistique multivariée a montré que le faible niveau d'instruction des mères, l'âge compris entre 1 et 5 ans, le fait de vivre dans un centre de soutien et les problèmes financiers augmentaient le risque de mortalité due à des traumatismes chez les moins de 5 ans (odds ratio $>1, p \leq 0,05$ ).

Conclusion : Compte tenu de l'importance et de l'impact des facteurs sociaux sur la mortalité liée aux traumatismes chez les enfants, les responsables de l'élaboration des politiques de santé devraient initialement prendre en compte l'approche des déterminants sociaux de la santé dans les programmes de santé de l'enfant afin d'orienter les interventions visant à réduire cette mortalité.

$$
\text { زالإسلامية اجتيرات اجتية تفسر وفيات الأطفال دون سن الخامسة الناجمة عن الإصابات في إقليم إصفهان، جمهورية إيران }
$$

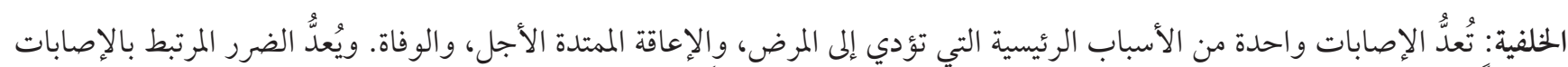

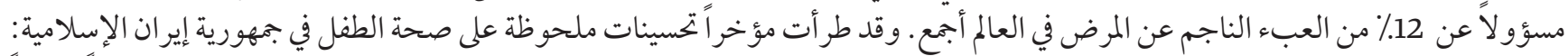

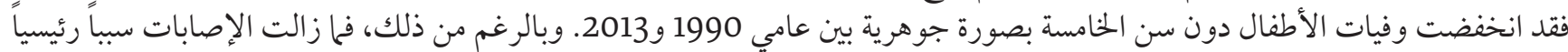
للوفاة في صفوف الأطفال في تلك الفئة العمرية.

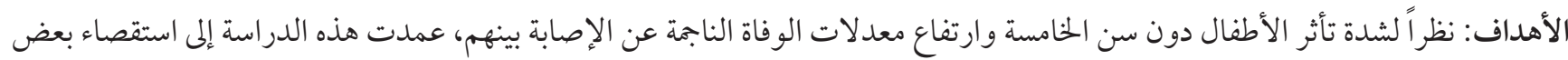

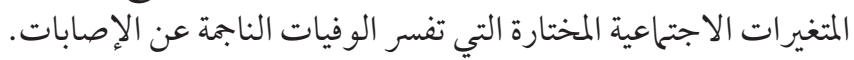

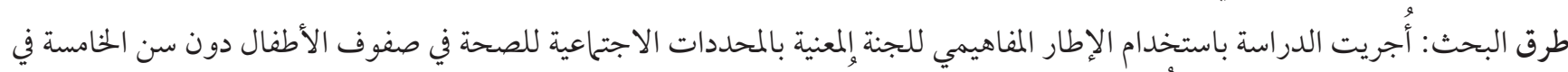

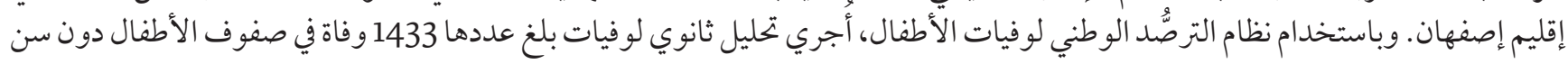
الخامسة في الفترة بين عامي 2010 و2015.

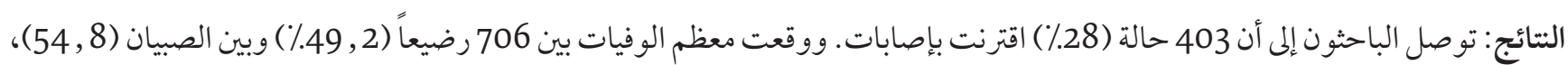
و الأطفال المقيمين في المناطق الحضرية (9 ور 78\%). وأظهر تحليل الانحدار اللوجستي المتعدد المتغيرات أن انخفاض المستوى التعليمي لدى أمهات 
الأطفال الذين تتراوح أعمارهم بين سنة وخمس سنو اته، و اللو اتي يعشن في مر اكز الدعم ويعانين من مشكلات مالية زاد من فرص حدوث وفيات

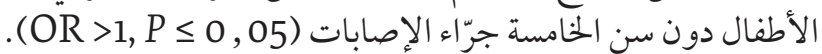

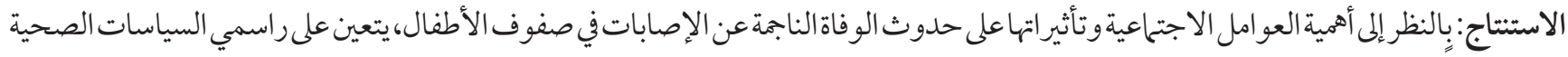

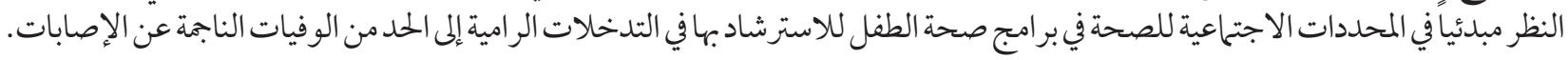

\section{References}

1. Vos T, Abajobir AA, Abate KH, Abbafati C, Abbas KM, Abd-Allah F, et al. Global, regional, and national incidence, prevalence, and years lived with disability for 328 diseases and injuries for 195 countries, 1990-2016: a systematic analysis for the Global Burden of Disease Study 2016. Lancet. 2017 Sep 16;390(10100):1211-59. doi:10.1016/So140-6736(17)32154-2.

2. Sridharan L, Crandall M. Injury and health among children in vulnerable families. J Trauma Acute Care Surg 2011;1;70(6):153945. doi:10.1097/TA.obo13e318219ob94

3. Khazaei S, Mazharmanesh S, Khazaei Z, Goodarzi E, Mirmoini R, Mohammadian-Hafshejani A, et al. An epidemiological study on the incidence of accidents in the Hamadan province during 2009 to 2014. Pajouhan Scientific J. 2016;14(2).

4. Injuries and violence: the facts. Geneva: World Health Organization; 2014.

5. Amirzadeh F, Tabatabaiee SH. The incidence rate and causes of accidents among the students of Shiraz guidance schools. J Kerman University of Medical Sciences. 2007;14(1):55-60.

6. Peden M. World report on child injury prevention. Geneva: World Health Organization; 2008.

7. Esmaeili Z, Vaezzadeh N. Injury patterns in children under 15 years of natural disasters in the province 1999-2000. J Mazandaran University of Medical Sciences. 2001;10(29):1-7.

8. Thein M, Lee B, Bun P. Childhood injuries in Singapore: a community nationwide study. Singapore Med J. 2005;46(3):116-21. PMID:15735875

9. Child poverty in perspective: An overview of child well-being in rich countries. Florence: UNICEF Innocenti Research Centre; 2007 (Report Card 7).

10. Rashidian A, Khosravi A, Khabiri R, Khodayari-Moez E, Elahi E, Arab M, et al. Islamic Republic of Iran's multiple indicator demographic and health survey (IrMIDHS) 2010. Tehran: Ministry of Health and Medical Education; 2012:83-6.

11. Alkema L, Chou D, Hogan D, Zhang S, Moller A-B, Gemmill A, et al. Global, regional, and national levels and trends in maternal mortality between 1990 and 2015, with scenario-based projections to 2030: a systematic analysis by the UN Maternal Mortality Estimation Inter-Agency Group. Lancet 2016;387(10017):462-74. doi:10.1016/So140-6736(15)oo838-7

12. You D, Hug L, Chen Y. Levels and trends in child mortality: report 2014. New York: United Nations Children's Fund; 2014.

13. Marmot M. Status syndrome. Significance. 2004;1(4):150-4. https://doi.org/10.1111/j.1740-9713.2004.00058.x

14. De Camargo Jr KR. Closing the gap in a generation: health equity through action on the social determinants of health. Global Public Health. 2010;6(1):102-5. doi:10.1080/17441692.2010.514617

15. Lim SS, Vos T, Flaxman AD, Danaei G, Shibuya K, Adair-Rohani H, et al. A comparative risk assessment of burden of disease and injury attributable to 67 risk factors and risk factor clusters in 21 regions, 1990-2010: a systematic analysis for the Global Burden of Disease Study 2010. Lancet. 2012;380(9859):2224-60. doi:10.1016/So140-6736(12)61766-8

16. The Statistical Report of the Islamic Republic of Iran. Tehran: Iranian Authority for General Department of Public Statistics and Statistical Center of Iran; 2011 (https://nnt.sci.org.ir/sites/Apps/yearbook/Lists/year_book_req/Item/newifs.aspx; accessed 28 July 2018)

17. Solar O, Irwin A. A conceptual framework for action on the social determinants of health. Social Determinants of Health Discussion Paper 2 (Policy and Practice). Geneva: World health Organization; 2010.

18. Rahbar M, Ahmadi M, Lornejad H, Habibelahi A, Sanaei-Shoar T, Mesdeaghinia A. Mortality causes in children 1-59 months in Iran. Iran J Public Health. 2013;42(Suppl. 1):93.

19. Delbarpoor AS, Tajedini F, Ehdaievand F, Moghimi DB, Farsar AR, Torkaman NS. Review of injuries leading to death in children aged 1 to 59 months in the area covered by Shahid Beheshti University of Medical Sciences from March 2011-March 2013. Safety Promot Inj Prev. 2013;1(4):205-11.

20. Kamal NN. Home unintentional non-fatal injury among children under 5 years of age in a rural area, El Minia Governorate, Egypt. J Community Health. 2013;38(5):873-9. doi:10.1007/s10900-013-9692-y.

21. Chowdhury AH. Determinants of under-five mortality in Bangladesh. Open J Stat. 2013;3(03):213.

22. Huda TM, Tahsina T, Arifeen SE, Dibley MJ. The importance of intersectoral factors in promoting equity-oriented universal health coverage: a multilevel analysis of social determinants affecting neonatal infant and under-five mortality in Bangladesh. Glob Health Action. 2016;9(1):29741. doi:10.3402/gha.v9.29741

23. Perry-Jenkins M, Gillman S. Parental job experiences and children's well-being: The case of two-parent and single-mother working-class families. J Fam Econ Issues. 2000;21(2):123-47. 
24. Reyes VS. The lived experiences of single Latina mothers and the multiple roles they manage [thesis]. Ann Arbor: Capella University; 2015.

25. Cairney J, Boyle M, Offord DR, Racine Y. Stress, social support and depression in single and married mothers. Soc Psychiatry Psychiatr Epidemiol. 2003;38(8):442-9. doi:10.1007/s00127-003-0661-0

26. Barak M, Sadeghieh Ahari S, Amani F, Asadi G, Rahimi G, Khadem E. Causatives and risk factors for deaths among infants under 1 year old in Ardabil slums during 2008-2009. J Ardabil University of Medical Sciences. 2012;12(5):40-7.

27. Singh A, Kumar A, Kumar A. Determinants of neonatal mortality in rural India, 2007-2008. PeerJ. 2013;1:e75. doi:10.7717/peerj.75

28. Mahfouz MS, Surur AA, Ajak DAA, Eldawi EA. Level and determinants of infant and child mortality in Malakal Town-southern Sudan. Sudanese L Public Health. 2009 Apr 1;4(2):250-5.

29. Kravdal $\varnothing$. Child mortality in India: Exploring the community-level effect of education. Oslo: Health Economics Research Programme, Oslo University; 2009.

30. Hasaniha M, Khodabandeloo M, Eskandari F, Mazloomzadeh S. Evaluation of socioeconomic factors in injured children at Mousavi and Valiasr hospitals of Zanjan. Community Health. 2016;2(3):165-71.

31. Rarani MA, Rashidian A, Khosravi A, Arab M, Abbasian E, Morasae EK. Changes in socio-economic inequality in neonatal mortality in Iran between 1995-2000 and 2005-2010: an Oaxaca decomposition analysis. Int J Health Policy Manag. 2017;6(4):219. doi:10.15171/ijhpm.2016.127

32. Sajjadi H, Vameghi M, Madani S. Social equity and health of children in Iran. Social Welfare. 2010;9(35):89-137.

33. Velemínský M, Průchová D, Vitošová A, Lavičková M, Stránský P. The relationship between family socioeconomic condition and childhood injury frequency in selected locations in the Czech Republic. Med Sci Monit. 2012;18(3):PH19-27. doi:10.12659/ msm. 882508 